Doi: $10.4274 /$ vhd. 38358

Viral Hepatitis Journal 2014; 20(2): 81-84

\title{
Dermatological Side Effects in a Patient with Hepatitis C Infection During Treatment with Pegylated Interferon/ Ribavirin+Telaprevir: A Case Report
}

\author{
Hepatit C Enfeksiyonu Olan Hastada Pegile Interferon/Ribavirin+Telaprevir Tedavisi \\ Sırasında Görülen Dermatolojik Yan Etki: Olgu Sunumu
}

\author{
Tuğba SARI1, Suda Tekin KORUK2, Fatih TEMOÇIN3 \\ ${ }^{1}$ Buldan Chest Diseases Hospital, Clinic of Infectious Diseases and Clinical Microbiology, Denizli, Turkey \\ 2 Harran University Faculty of Medicine, Department of Infectious Diseases and Clinical Microbiology, Şanlıurfa, Turkey \\ 3 Yozgat Hospital, Clinic of Infectious Diseases and Clinical Microbiology, Yozgat, Turkey
}

\begin{abstract}
Chronic hepatitis C (HCV)and pegylated interferon(peg-IFN)/ribavirin (RBV) treatment dermotological side effects are well known. New direct-acting antivirals have led to significant improvements in sustained virologic response rates, but several have led to an increase in dermatological side affects versus peg-IFN/RBV alone. A 55year old man was administered peg-IFN alpha-2a $180 \mathrm{mcg} /$ one times a week, RBV $1200 \mathrm{mg} /$ day and telaprevir $2250 \mathrm{mg} /$ day with the diagnosis of chronic hepatitis C. Around the 8th week of the treatment the patient presented with itching eruptions on his face, neck, anterior wall of the and the forearm. A twelve administration of the combination therapy, the patient admitted to our hospital itching, rash, edema in whole body and facial edema and peeling in his facial skin. As a result, with the advent of the new direct-acting antivirals, dermatological manifestations will be seen more frequently so patients should be monitored closely in terms of dermatological side effects. (Viral Hepatitis Journal 2014; 20(2): 81-84)

Key words: Rash, hepatitis $\mathrm{C}$, pegylated interferon, ribavirin, telaprevir
\end{abstract}

ÖZET

Hepatit C virüs (HCV) infeksiyonuna ve pegile interferon (peg-IFN)/ribavirin (RBV) tedavisine bağlı dermatolojik yan etkiler görülebilir. Yeni direkt etkili antiviraller kalıcı virolojik yanıt oranlarında önemli artışlara neden olmuştur, ancak yalnız peg-IFN/RBV tedavisine göre ise dermatolojik yan etkilerde artışa yol açmıştır. Elli beş yaşında erkek hastaya kronik hepatit C tanısıyla peg-IFN alfa-2a 180 mcg/haftada, RBV 1200 $\mathrm{mg} / \mathrm{gün}$ ve telaprevir $2250 \mathrm{mg} / \mathrm{gün}$ tedavisi başlandı. Tedavinin sekinci haftasında hastanın yüzünde, boynunda, göğüs ön yüzünde ve ön kolda kaşıntılı erupsiyonlar oluştu. Hasta tedavinin 12. haftasında bütün vücutta kaşıntı, döküntü, facial ödem ve soyulma şikayetiyle hastaneye başvurdu. Sonuç olarak direk etkili antivirallerin dermatolojik yan etkileri çok daha sık görüldüğünden, bu hastaların dermatolojik yan etkiler açısından yakın takip edilmeleri gerekmektedir. (Viral Hepatit Dergisi 2014; 20(2): 81-84)

Anahtar Kelimeler: Döküntü, hepatit, pegile interferon, ribavirin, telaprevir

\section{Introduction}

The worldwide incidence of hepatitis $\mathrm{C}$ virus $(\mathrm{HCV})$ infection is between $1 \%$ and $5 \%$. In our country the incidence of $\mathrm{HCV}$ infection was reported to be $1 \%-2.4 \%$. These ratios vary between $0.05 \%-51.6 \%$ in different populations (1).

The standard treatment for chronic hepatitis $\mathrm{C}$ infection is based on a combination of pegylated interferon (peg-IFN) and ribavirin (RBV). This treatment is associated with a variety of mild or severe adverse events, such as flu-like symptoms, rash, anemia, trombocytopenia, neutropenia and depression (2). The incidence of dermatological adverse events associated with peg-IFN alpha 2a or alfa 2b/RBV during treatment for hepatitis C infection is $>10 \%$ (3). Sometimes it can be difficult to distinguish cutaneous signs and symptoms of hepatitis $\mathrm{C}$ from interferon treatment-related adverse events (4).

New direct-acting antivirals have led to significant improvements in sustained virologic response rates, but several have led to an increase in dermatological side affects versus peg-IFN/RBV alone. It has been reported that dermatological adverse events are seen in approximately half of patients receiving peg-IFN/RBV+telaprevir treatment $(5,6)$. Here, we report a case of dermatological adverse event that occurred during peg-IFN/RBV+telaprevir treatment.

Address for Correspondence: Tuğba Sarı MD, Buldan Chest Diseases Hospital, Clinic of Infectious Diseases and Clinical Microbiology, Denizli, Turkey 


\section{Case}

A 55-year-old male patient admitted to our outpatient clinic in 2009 after he was found to be anti HCV (+) during his routine blood tests. In 2009, his tests revealed: anti-HCV (+), HBsAg $(-)$, anti-HBc IgG $(+)$, anti-HBs $(+)$, anti-HAV total $(+)$, anti-HIV $(-)$, aspartate transaminase (AST): $48 \mathrm{IU} / \mathrm{mL}$, alanine transaminase (ALT): $73 \mathrm{lU} / \mathrm{mL}$. His protein/albumin ratio was $7.1 / 3.6 \mathrm{~g} / \mathrm{dL}$, alpha fetoprotein levels were normal, HCV RNA: $1.23 \times 10^{8} \mathrm{IU} /$ $\mathrm{mL}$ and genotype was $1 \mathrm{~b}$. Hepatobiliary ultrasonography (US) revealed grade 1 hepatosteatosis and a minimal thickening in liver paranchyma. A liver biopsy revealed: a HAl score of 6-18 and fibrosis stage of 5-6. The patient was prescribed peg-IFN alpha 2a $180 \mathrm{mcg} /$ once a week + RBV $1200 \mathrm{mg} / \mathrm{day}$. During followup, no significant hematological side effect was observed but he was started on mirtazapin due to a psychiatric adverse event (depression). The treatment was discontinued after 6 months because of partial response. The follow-up data of the patient in 2009 is shown in (Table 1).

During the follow-up period in 2010, treatment with pegIFN alpha 2b 120mcg/once a week+ RBV 1200 mg/day was readministered after his blood tests revealed HCV RNA: $8.01 \times 10^{6}$ $\mathrm{IU} / \mathrm{mL}$, ALT: $97 \mathrm{IU} / \mathrm{mL}$, AST: $48 \mathrm{lU} / \mathrm{mL}$. He was prescribed an antidepressant (escitalopram) after his psychiatric evaluation before treatment. Although we obtained a response to the treatment, the treatment was discontinued because the patient was not compliant with the treatment, did not agree to continue using the drugs and also had major depression. The follow up data of the patient in 2010 is presented in (Table 1).

In 2013, the patient was started on peg-IFN alpha 2a 180 mcg/once a week+RBV 1200 mg/day+telaprevir 2250mg/day after his test results revealed HCV RNA: 7.41×106 IU/mL, ALT: 30 $\mathrm{IU} / \mathrm{mL}, A S T: 30 \mathrm{IU} / \mathrm{mL}$. In the fourth week of this treatment, the following values were obtained: HCV RNA: negative, ALT: 22 IU/ $\mathrm{mL}$ and AST: $26 \mathrm{IU} / \mathrm{mL}$. Around the 8th week of the treatment the patient presented with itchy rashes on his face, neck, and anterior wall of the forearm (Figure 1). Upon consultation with the dermatology clinics he was initiated urea solution and methylprednisolone aceponate solution. Treatment for HCV was continued without interruption. After $12^{\text {th }}$ administration of the combination therapy, the patient was admitted to our hospital with the complaints of itching, rash, edema generalized to

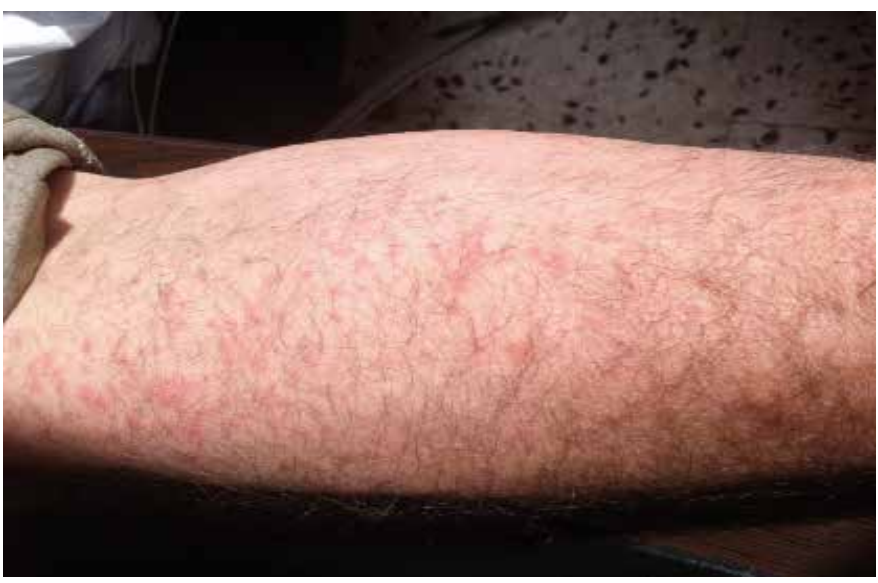

Figure 1. At the eighth weeks of the treatment (itching eruptions). the whole body and facial edema and peeling skin on his face (Figure 2). His physical examination revealed body temperature of $36.7^{\circ} \mathrm{C}$, blood pressure of $110 / 70 \mathrm{mmHg}$, and heart rate of $80 /$ min. There were no lymphadenopathy and oral mucosal lesions. All other system evaluations revealed normal findings except for dermatologic lesions. The patient was hospitalized and intravenous hydration was started together with antihistamines and he also continued on his previous lotions to be applied on whole body skin. His blood tests were negative for HCV RNA. Then peg-IFN/ $\mathrm{RBV}+$ telaprevir treatment was interrupted for a week. Four days after treatment discontinuation, the rashes improved, edema and peeling diminished. One week peg-IFN/RBV treatment without telaprevir was readministered. At 24th week of this treatment the patient was negative for HCV RNA and the treatment was stopped. The followup data for the patient in 2013 is presented in (Table 1).

\section{Discussion}

$\mathrm{HCV}$ infection causes a variety of dermatological reactions in addition to liver inflammation and fibrosis (7-9). During HCV infection cryoglobulin increases with a ratio of $40 \%-84 \%$ and in $15 \%$ of patients cryoglobulinemic vasculitis develops. The most common viral cause of porfiria cutanea tarda is HCV. Also an increased incidence of lichen planus is reported in patients infected with $\mathrm{HCV}$ compared to those who are not infected. Despite absence of adequate evidence, cutaneous polyarteritis nodosa, psoriasis, urticaria, erythema multiforme can be associated with HCV (7-9).

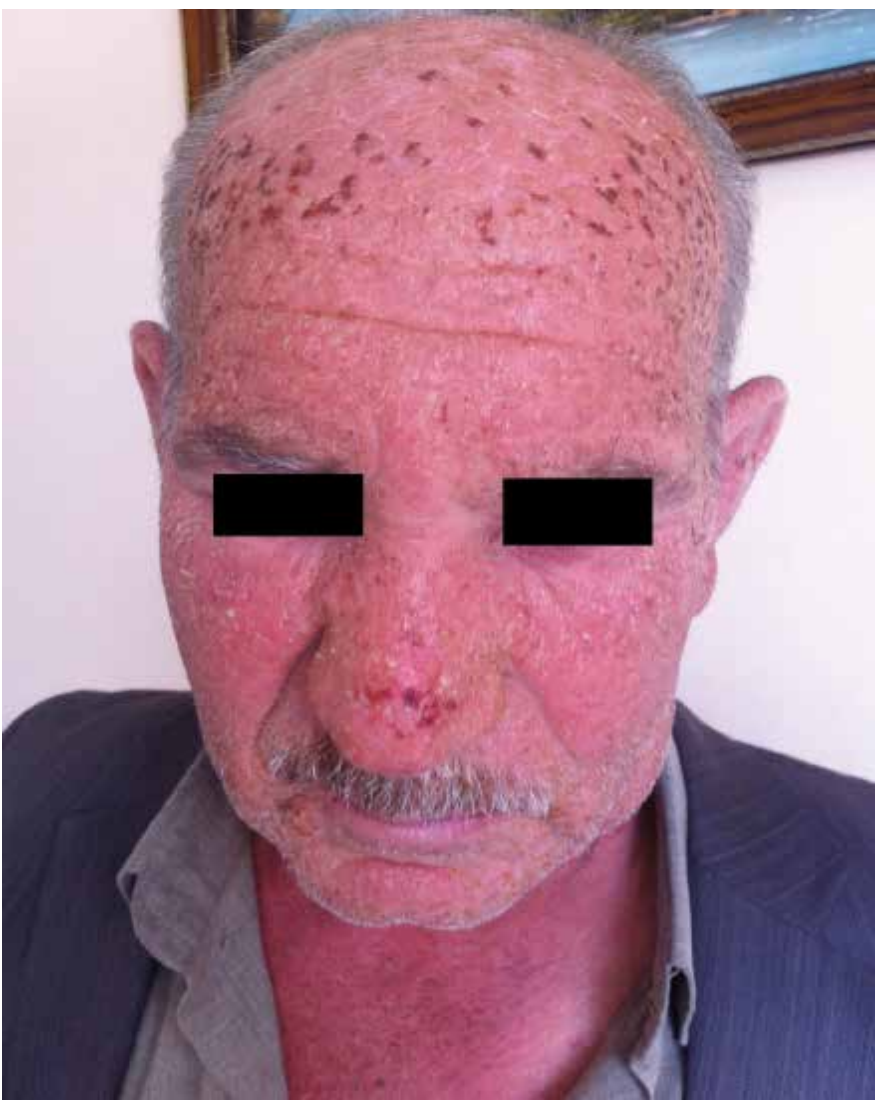

Figure 2. At the $12^{\text {th }}$ weeks of the treatment (rash, edema in whole body and facial edema and peeling in his facial skin). 
Mixed cryoglobulinemia, porphyria cutanea tarda, lichen planus and, although without sufficient evidence, cutaneous polyarteritis nodosa, psoriasis, urticaria and erythema multiforme can be associated with $\mathrm{HCV}$ infection. Localized reactions associated with the use of peg-IFN and RBV are erythemotous or egzematous dermatitis, psoriasis, localized alopecia, skin ulceration and necrosis, local infections at sites of injection, and localized allergic reactions (4,10-12). Generalized reactions include increase in chronic inflammatory diseases of the skin, such as alopecia/abnormal hair growth, dry skin, dermatitis, itching, psoriasis, lichen planus and also immunie-related inflammatory diseases and autoimmune diseases like psoriasis and sarcoidosis $(4,10,13-15)$.

When evaluating the treatment of chronic hepatitis $\mathrm{C}$ over 22 years, we can observe that the addition of protease inhibitors (telaprevir, boceprevir) to peg-IFN/RBV treatment resulted in a sustained viral response rate of $80 \%$ of. In patients infected with HCV genotype 1, the addition of a recently approved protease inhibitor telaprevir to peg-IFN/RBV resulted in sustained viral response rates of approaching $75 \%$ for treatment-naive patients and $80 \%$ for relapsing patients after initial peg-IFN/RBV. Another protease inhibitor boceprevir resulted in similarly high response rates of $68 \%$ and $75 \%$ for treatment naive patients and relapsing patients, respectively $(16,17)$.

Protease inhibitors (telaprevir, boceprevir) can provide clinicians with shorter durations of treatment while ensuring higher response rates. Nevertheless, they are associated with more adverse events and drug interactions (11).

While eruptions are seen in 33\% of those treated with peg-IFN/ RBV this rates are approaching to $50 \%$ (90\% of these are mildmoderate, $50 \%$ occurred in the first 4 weeks) in patients receiving peg-IFN/RBV+telaprevir. Less than $10 \%$ of those patients with eruptions progressed to a more severe stage, $0.4 \%$ progressed to DRESS (a drug eruption associated with eosinophilia and systematic symptoms) and $0.1 \%$ progressed to Stevens-Johnson syndrome (11).

The management of rash is suggested to be as the following: follow up if it is localized; dermatologic consultation when involving $<50 \%$ of body surface area; dermatologic consultation, interruption and then permanent discontinuation of the treatment in case of no improvement if it effects $>50 \%$ of body surface area (18). In our case, telaprevir treatment was discontinued since skin eruption was effecting $>50 \%$ of body surface area. It is suggested to internalize the patient, discontinue the treatment with telaprevir+peg-IFN/RBV and consult to dermatologists if there

Table 1. Follow- up data during treatment

\begin{tabular}{|l|l|l|l|l|}
\hline \multicolumn{2}{|c|}{} & Start of treatment & $1^{\text {th }}$ week & 24 $^{\text {th }}$ week \\
\hline 2009 & HCV RNA (IU/mI) & $1.23 \times 10^{8}$ & $9.78 \times 10^{6}$ & $2.71 \times 10^{6}$ \\
& ALT (IU/mI) & 73 & 30 & 32 \\
& AST (IU/ml) & 48 & 32 & 30 \\
\hline 2010 & HCV RNA (IU/mI) & $8.01 \times 10^{6}$ & $1.13 \times 10^{4}$ & 29 \\
& ALT (IU/ml) & 97 & 50 & 15 \\
& AST (IU/ml) & 48 & 35 & 17 \\
\hline 2013 & HCV RNA (IU/ml) & $7.41 \times 10^{6}$ & $(-)$ & $(-)$ \\
& ALT (IU/ml) & 30 & 30 & 27 \\
& AST (IU/ml) & 22 & 26 & 24 \\
\hline
\end{tabular}

are disseminated bullous eruptions, DRESS syndrome, StevensJohnson syndrome, acute generalized exanthematous pustulosis and erythema multiforme (18).

\section{Conclusions}

In conclusion, since eruptions occur in nearly half of patients receiving telaprevir+peg-IFN/RBV, it is crucial that these patients are followed up for dermatological adverse events. Patients should be advised before the initiation of the treatment to limit exposure to sun/heat and to regularly apply lotions after shower that would prevent dry and itchy skin.

\section{Conflict of interest: None declared.}

\section{References}

1. Tozun N, Ozdogan O, Cakaloglu Y, Idilman R, Karasu Z, Akarca $S$, et al. A Nationwide prevalence study and risk factors for hepatitis A, B, C and D infections in Turkey. Hepatology. 2010; 52(Suppl 1); 697

2. Dusheiko G. Side effects of alpha interferon in chronic hepatitis C. Hepatology. 1997; 26(Suppl 1): 112-21.

3. Charron A, Bessis D, Dereure O, Guilhou JJ, Guillot B. Local cutaneous side effects of interferons. Presse Med. 2001; 30: 1555-60.

4. Lubbe J. Dermatological side effects. Hot Topics in Viral Hepatitis. 2008; 9: 29-35.

5. McHutchison JG, Everson GT, Gordon SC, Jacobson IM, Sulkowski M, Kauffman R, et al; Telaprevir with peginterferon and ribavirin for chronic HCV genotype 1 infection. N Engl J Med. 2009; 360: 1827-38.

6. Thompson A, Patel K, Tillman H, McHutchison JG. Directly acting antivirals for the treatment of patients with hepatitis $C$ infection: a clinical development update addressing key future challenges. J Hepatol. 2009; 50: 184-94.

7. Sène $D$, Limal N, Cacoub P. Hepatitis C virus-associated extrahepatic manifestations: a review. Metab Brain Dis. 2004; 19(3-4): 357-81.

8. Jacobson IM, Cacoub P, Dal Maso L, Harrison SA, Younossi ZM. Manifestations of chronic hepatitis $C$ virus infection beyond the liver. Clin Gastroenterol Hepatol. 2010; 8(12): 1017-29.

9. Cacoub P, Poynard T, Ghillani P, Charlotte F, Olivi M, Piette JC, et al. Extrahepatic manifestations of chronic hepatitis C. MULTIVIRC Group. Multidepartment Virus C. Arthritis Rheum. 1999; 42(10): 2204-12.

10. Mistry N, Shapero J, Crawford RI. A review of adverse cutaneous drug reactions resulting from the use of interferon and ribavirin. Can J Gastroenterol. 2009; 23(10): 677-83.

11. Lang AM, Norland AM, Schuneman RL, Tope WD. Localized interferon alfa-2b-induced alopecia. Arch Dermatol. 1999; 135(9): 1126-8.

12. Dalmau J, Pimentel CL, Puig L, Peramiquel L, Roé E, Alomar A. Cutaneous necrosis after injection of polyethylene glycolmodified interferon alfa. J Am Acad Dermatol. 2005; 53(1): 62-6.

13. Lübbe J, Kerl K, Negro F, Saurat JH. Clinical and immunological features of hepatitis $\mathrm{C}$ treatment-associated dermatitis in 36 prospective cases. $\mathrm{Br} J$ Dermatol. 2005; 153(5): 108890.

14. Quesada JR, Gutterman JU. Psoriasis and alpha-interferon. Lancet. 1986; 1: 1466-8. 
15. Fantini F, Padalino C, Gualdi G, Monari P, Giannetti A. Cutaneous lesions as initial signs of interferon alpha-induced sarcoidosis: report of three new cases and review of the literature. Dermatol Ther. 2009; 22(Suppl 1): 1-7.

16. Cunningham M, Foster GR. Efficacy and safety of telaprevir in patients with genotype 1 hepatitis $C$ infection. Therap Adv Gastroenterol. 2012; 5(2): 139-51.
17. Habersetzer F, Leboeuf C, Doffoël M, Baumert TF. Boceprevir and personalized medicine in hepatitis $C$ virus infection. Pharmgenomics Pers Med. 2012; 5: 125-37.

18. Cacoub P, Bourlière M, Lübbe J, Dupin N, Buggisch P, Dusheiko $G$, et al. Dermatological side effects of hepatitis $C$ and its treatment: Patient management in the era of direct-acting antivirals. J Hepatol 2012; 56(2): 455-63. 